\title{
STRUKTUR BIAYA DAN SKALA USAHA EKONOMIS PENGGILINGAN KOPI BUBUK DI KOTA BENGKULU
}

\author{
(Cost Structure And Economic Scale Of Coffee Processing In Bengkulu City) \\ M. Mustopa Romdhon \\ Jurusan Sosial Ekonomi Pertanian \\ Fakultas Pertanian Universitas Bengkulu
}

\begin{abstract}
The coffee has an economic prospective for Bengkulu PDRB since it is regional key commodity. But limitation of capital, production technology, and market information have made this business on stagnation condition. The research is aimed to elaborate the economic scale of coffee processing at Bengkulu Municipal. Processing coffee industries at Bengkulu city face with finacial, production technology and market information burdens, generally. Its later affect to the industrys' economic scale Commonly, the processoris stil in decreasing return to scale,where the optimalitation on production factors usage could lead the processor to optimal capacity of production

Key words: economic scale, cost structure, coffee processor
\end{abstract}

\section{PENDAHULUAN}

Prospek pengembangan komoditas kopi bubuk ke depan masih memberikan harapan baik karena peningkatan permintaan kopi bubuk oleh industri makanan mengingat kopi bubuk mempunyai keterkaitan yang erat baik kebelakang maupun ke depan dengan industri penggilingan makanan. Diperkirakan kelompok industri makanan yang menggunakan bahan baku kopi bubuk antara lain industri kue-kue basah, industri kopi instan, serta industri es krim. Kondisi ini menunjukkan di masa depan permintaan kopi bubuk untuk bahan baku produk industri semakin intensif, seiring dengan semakin berkembangnya jenis industri pengguna kopi bubuk sebagai bahan baku. Peningkatan permintaan kopi bubuk juga berasal dari konsumsi langsung masyarakat terutama di Propinsi Bengkulu dan Indonesia, dimana sudah sejak lama masyarakat kita dikenal mengkonsumsi kopi. Hal ini tentunya membuka peluang pasar sangat besar bagi industri kecil kopi bubuk di Kota Bengkulu. Kopi bubuk selama ini telah memenuhi permintaan bahan baku industri makanan dan konsumsi langsung masyarakat. Pangsa pasarnya mencakup 
pasar lokal Propinsi Bengkulu, regional Sumatera, nasional bahkan ekspor ke mancanegara.

Prospek komoditi ini semakin menjanjikan karena bahan baku untuk pembuatan kopi bubuk merupakan komoditas unggulan daerah serta ketersediaannya berlimpah dalam menunjang pengembangan industri kecil kopi bubuk. Luas tanaman kopi di Propinsi Bengkulu sebesar 68.524 ha dengan produksi kopi bubuk mencapai 54.843 ton atau produktifitas rata-rata sebesar 0.80 $\mathrm{kg} / \mathrm{ha}$. Dari bahan baku tersebut mampu dihasilkan kopi bubuk dengan nilai produksi sebesar Rp.3 miliar lebih selama tahun 2003. Nilai produksi ini hanya sebagian dari produksi bahan baku yang ada,sedangkan sisanya diduga kuat diolah dan dipasarkan ke luar Propinsi Bengkulu. Namun penerimaan dari komoditi kopi diperkirakan akan terus meningkat sampai dengan 2010 mencapai Rp 58.232.000.000 jika kondisi idealnya terus dipertahankan (Hafsari, 2004; Juita, 2004 ). Apalagi bila semua bahan baku tersebut diolah menjadi kopi bubuk pada industri penggilingan lokal untuk memenuhi pangsa pasar yang telah ada sehingga memberikan nilai tambah yang lebih tinggi bagi perekonomian daerah secara keseluruhan.

Namun peluang pasar yang menjanjikan keuntungan besar serta didukung oleh bahan baku yang besar, belum mampu dimanfaatkan oleh industri penggilingan kopi bubuk secara maksimal. Dewasa ini industri kopi bubuk mengalami perkembangan relatif lambat. Penyebabnya adalah pelaku usahanya menghadapi permasalahan penggilingan skala usaha kecil, yang dicirikan oleh volume produk-produk yang dihasilkan keadaan kualitas dan kuantitasnya belum sesuai dengan keinginan pasar. Permasalahan komoditi kopi lainnya adalah menurut (Wardhani dan Herman, 2000) disebabkan oleh pangsa produksi kopi mutu rendah (IV-VI), masih di atas $85 \%$ dan kurang dari $15 \%$ produksi kopi bermutu. Pengrajin kopi bubuk masih menghadapi permasalahan mendasar menyangkut ketidakpastian pasar dan mengalami fluktuasi harga yang besar. Permainan harga oleh para pelaku di pasar tradisional menyebabkan bagian harga yang diterima relatif lebih kecil, bagian dari pendapatan yang dipergunakan untuk pengembangan usaha tidak siknifikan untuk mencapai skala usaha ekonomis. Penelitian ini bertujuan untuk menngeksplorasi struktur biaya usaha serta mengestimasi skala usaha ekonomis industri kecil penggilingan kopi bubuk di Kota Bengkulu.

36 M. Mustopa Romdhon. Struktur Biaya dan Skala Usaha Ekonomis Penggilingan Kopi 


\section{KERANGKA PEMIKIRAN}

Karakteristik permintaan pasar komoditas tidak bersifat homogen, jika dibandingkan dengan pasar komoditas sector riil yang diasilkan oleh industri manufaktur, jasa dan perdagangan (Hayami dan Ruttan, 1984). Dengan sifat permintaan yang didominasi oleh skala usaha kecil-kecil tersebut, tidaklah mengherankan jika kebanyakan industri kecil kopi bubuk beroperasi secara tidak layak dan tidak ekonomis dengan tingkat produksi baik secara kuantitas maupun kualitas relatif rendah sehingga kepastian harga sulit untuk terwujud secara sempurna. Kondisi ini menyebabkan industri kecil kopi bubuk mengalami skala tidak ekonomis. Penyebab dari skala tidak ekonomis antara lain mismanajemen baik teknis maupun ekonomis, ketiadaan pekerja yang terampil, dan keburukan administrasi serta kondisi kelembagaan produksi maupun pasar yang terfrgamentasi.

Fungsi produksi menggambarkan hubungan teknis antara penggunaan input dan output yang dihasilkan dalam proses produksi (Coelli et al, 1998). Dimana tingkatan pengembalian berdasarkan skala usaha yang menunjukkan hubungan antara output dari suatu produk dengan input yang digunakan dalam jangka panjang digambarkan melalui konsep return to scale (RTS) (Pass et al, 1998; Samuelson et al, 1992, dan Coelli et al, 1998). Sebagai konsep jangka panjang retrun to scale terbagi menjadi 3, yaitu constant, increasing dan decreasing return to scale. Kondisi constant RTS terjadi bilamana peningkatan secara proporsional semua input $(k)$ akan meningkatkan output dalam proporsi yang sama $(k)$. Increasing RTS jika output meningkatkan lebih besar dari $k$ input, dan decreasing RTS jika tambahan output lebih kecil dari $k$ input.

Menurut Coelli et al (1998) kondisi rasional bagi industri kecil kopi bubuk adalah jika industri tersebut mempunyai kondisi constant RTS, dimana biaya penggunaan faktor produksi mencapai minimum pada tingkat produksi maksimum. Dalam kondisi ini, jika industri ingin meningkatkan produksi sebesar $\mathrm{k}$ maka industri dimaksud harus menambah seluruh faktor input sebesar $k$ pula. Dalam kondisi Increasing RTS berarti industri kecil kopi bubuk belum bekerja penuh, biaya rata-rata masih di atas biaya minimum, peningkatan produksi akan menyebabkan biaya rata mendekati biaya minimum. Kondisi ini umumnya 
ISSN: $1412-8837$

ditemukan pada industri. Sedangkan kondisi decreasing RTS industri kecil kopi bubuk berproduksi dengan biaya rata-rata diatas biaya minimum dan peningkatan produksi selalu disertai dengan peningkatan biaya yang lebih besar. Kondisi menyebabkan industri kecil kopi bubuk mengalami skala tidak ekonomis. Penyebab dari skala tidak ekonomis antara lain mismanajemen, ketiadaan pekerja yang terampil, dan keburukan administrasi serta kondisi kelembagaan produksi maupun pemasaran yang terfrgamentasi.

Indikasi-indikasi mismanajemen dalam pengelolaan industri penggilingan kopi bubuk di Kota Bengkulu secara ekonomi dapat dari sisi teknis dan finansial. Secara teknis menurut Wardhani dan Herman, (2000) pengelolaan yang baik diketahui dari dari sejauhmana alokasi dan ketersediaan input produksi seperti bahan baku kopi, bahan bakar, serta peralatan produksi secara sesuai dan tepat. Selain input produksi yang teralokasi secara baik juga dibutuhkan tenaga kerja untuk produksi dan manajemen yang tidak hanya berpengalaman tetapi juga terampil.

Secara finansial menurut Anwar (2002) dan Romdhon (2004) dapat diketahui dari seberapa besar keuntungan yang diperoleh pihak manajemen. Aspek-aspek tersebut secara bersama-sama akan menghasilkan kopi bubuk berkualitas. Keberhasilan perusahaan untuk menghasilkan output bermutu yang diterima dengan harga tinggi ditentukan oleh sistem kelembagaan produksi maupun pemasaran yang berjalan secara professional. Indikasi kelembagaan dapat dilihat pola pengelolaan sumberdaya keuangan apakah proporsi penggunaan modal sendiri atau modal pinjaman lebih besar atau sebaliknya. Jumlah pinjaman yang besar akan memberikan insentif berusaha yang lebih besar sehingga mampu menghasilkan keuntungan dan sekaligus melunasi pinjaman .

\section{METODE PENELITIAN}

\section{Pengumpulan Data}

Penelitian ini dilaksanakan di Kota Bengkulu yang sebagian besar berada di pusat perbelanjaan dan perekonomian yaitu Pasar Mingu dan Pasar Panorama selama 8 (delapan) bulan. Pengumpulan data dilakukan dengan metode wawancara dan observasi terhadap responden yang penarikannya dilakukan secara sensus terhadap keseluruhan populasi yaitu 22 industri penggilingan kopi bubuk tahun 2007. Terutama responden yang memenuhi kriteria sebagai pengrajin dan sekaligus

38 | M. Mustopa Romdhon. Struktur Biaya dan Skala Usaha Ekonomis Penggilingan Kopi 
pemilik industri penggilingan kopi bubuk (Singarimbun, M dan Sofyan Effendi, 1995; Nugroho, 2000).

\section{Pengolahan Data}

Model ekonometrika berikut (Rubienfield dan Pindyk, 1997) digunakan untuk menjawab tujuan penelitian tersebut. Industri kecil kopi bubuk dalam penelitian ini diasumsikan memenuhi azas memaksimumkan keuntungan. Mengingat produk yang dihasilkan satu jenis oleh karena itu dalam analisis digunakan pendekatan single output. Industri kecil kopi bubuk yang mempunyai fungsi keuntungan single output yang secara umum dapat dirumuskan melalui proses penurunan matematika sebagai berikut:

$$
\begin{aligned}
& \Pi=p Q-\sum w * i X * i \ldots \ldots \ldots \ldots . .(1) \\
& Q=f(X * i, Z i) \ldots \ldots \ldots \ldots \ldots \ldots \ldots . .(2) \\
& C=\sum W * i X * i \ldots \ldots \ldots \ldots \ldots . .(3)
\end{aligned}
$$

Dimana: $\pi=$ keuntungan, $\mathrm{Q}=$ jumlah/fungsiproduksi, $\mathrm{p}=$ harga output per $\mathrm{kg}$, $\mathrm{X}^{*}{ }_{\mathrm{i}}=$ input peubah, $\mathrm{W}^{*_{\mathrm{i}}=}$ harga input $\mathrm{X}_{\mathrm{i}}$ dan $\mathrm{Z}$ i= input tetap. Persamaan (1) memperlihatkan bahwa keuntungan merupakan selisih pendapatan dengan biaya produksi. Syarat tercapainya keuntungan maksimum adalah jika tambahan penggunaan input memberikan tambahan keuntungan sebesar nol. Melalui persamaan (2) dapat dicari berapa nilai $X^{*}{ }_{i}=X_{i}$ optimum untuk mendapatkan keuntungan maksimum. Dengan mensubstitusikan nilai $X_{i}$ ke dalam (1) dan jika semua suku dibagi dengan $\mathrm{p}$ yakni $\pi / \mathrm{p}$ dan $\mathrm{w}_{\mathrm{i}}=\mathrm{W}^{*} \mathrm{i} / \mathrm{p}$ maka diperoleh fungsi keuntungan umum yang telah dinormalisasi sebagai berikut:

$$
\bigcap=\pi / p=F\left(w^{*} i, Z i\right) \ldots \ldots . . .(4)
$$

Untuk $\pi=$ keuntungan maksimum yang telah dinormalisasi,$\cap=$ fungsi keuntungan maksimum. Berikutnya spesifikasi fungsi keuntungan industri kecil kopi bubuk yang digunakan merupakan fungsi keuntungan cobb-douglas yang diturunkan dari fungsi produksi. Melalui derivasi dari persamaan (1) sampai (4) maka bentuk spesifikasi fungsi keuntungan Cobb Douglas sebagai berikut.

$\ln \cap=\ln A o+\alpha_{1} \ln X_{1}+\alpha_{2} \ln X_{2}+\alpha_{3} \operatorname{Ln} X_{3}+\alpha_{4} \ln X_{4}+\beta_{1} \operatorname{Ln} X_{1}+\beta_{2} \operatorname{Ln} X_{2}+\beta_{3} \ln X_{3}+\beta_{4} \ln X_{4}+\beta_{4} \ln X_{4}+e$ 
ISSN: $1412-8837$

Dimana:

$\cap \quad=$ Keuntungan maksimum yang telah dinormalisasi dengan harga output

$\mathrm{A}=$ intercept

$\mathrm{X}_{1} \quad=$ Upah tenaga kerja yang dinormalisasi dengan harga output

$\mathrm{X}_{2}=$ Harga bahan bakar yang dinormalisasi dengan harga output

$\mathrm{X}_{3}=$ Harga Pengemasan kopi bubuk yang dinormalisasi dengan harga output

$\mathrm{X}_{4}=$ Harga bahan baku kopi bubuk yang dinormalisasi dengan harga output

$\mathrm{X}_{5}=$ Jumlah investasi sebagai input tetap

$\mathrm{X}_{6}=$ Lokasi $($ Pasar Minggu $=1 ;$ Pasar Panorama $=0)$

$\mathrm{X}_{7}=$ Izin Usaha (ada=1; tidak $=0$ )

$\alpha_{i} \beta \mathrm{i},=$ koefisien regresi

$e_{i} \quad=$ Galat

Khusus untuk kuantifikasi peubah kualitatif dilakukan dengan melihat derajatnya melalui pengukuran skala ordinal yaitu 1 dan 0 (Hobbs, 1997; Hendayana,1998; Nawireja, 2002), berdasarkan persepsi produsen/pengrajin terhadap pertanyaan yang diajukan. Dimana nilai 1 menunjukkan adanya pinjaman modal dari luar sedangkan nilai 0 sebaliknya modal sendiri.

Untuk mengetahui apakah industri kecil kopi bubuk mempunyai kondisi constant, increasing, dan decreasing RTS dapat diuji dengan menggunakan koefisien input tetap dari fungsi keuntungan Cobb Douglas dengan menggunakan perhitungan serta kriteria sebagai berikut:

1. Jika $\sum \beta \mathrm{i}, \quad=1$ maka industri kecil kopi bubuk mempunyai kondisi Constant RTS

2. Jika $\sum \beta \mathrm{i}, \quad>1$ maka industri kecil kopi bubuk mempunyai kondisi Increasing RTS

3. Jika $\sum \beta \mathrm{i}, \quad<1$ maka industri kecil kopi bubuk mempunyai kondisi Decreasing RTS.

\section{HASIL DAN PEMBAHASAN}

Indikasi-indikasi mismanajemen dalam pengelolaan industri penggilingan kopi bubuk di Kota Bengkulu merujuk kepada pendapat Anwar, 2002 dan Romdhon, 2004 serta Wardhani dan Herman, 2000 dapat diketahui dari aspek ekonomi dapat dari sisi teknis dan finansial. Secara teknis pengelolaan yang baik

40 | M. Mustopa Romdhon. Struktur Biaya dan Skala Usaha Ekonomis Penggilingan Kopi 
diketahui dari dari sejauhmana alokasi dan ketersediaan input produksi seperti bahan baku kopi, bahan bakar, serta peralatan produksi secara sesuai dan tepat. Selain input produksi yang teralokasi secara baik juga dibutuhkan tenaga kerja untuk produksi dan manajemen yang tidak hanya berpengalaman tapi juga terampil. Sedangkan secara finansial dapat diketahui dari seberapa besar kompisisi penggunaan biaya varaibel dan biaya tetap serta keuntungan yang diperoleh pihak manajemen.

\section{Struktur Biaya Penggilingan Kopi Bubuk Persentase Biaya Variabel}

Komposisi biaya produksi yang merupakan akumulasi biaya tetap dan biaya variabel pada industri penggilingan kopi bubuk di Kota Bengkulu, menunjukkan bahwa sebagian besar biaya produksi di peruntukkan untuk operasional produksi. Biaya bahan baku utama memberikan kontribusi terbesar terhadap penggunaan biaya variabel , kemudian biaya tenaga kerja dan biaya bahan penolong (pembelian jagung) untuk kategori kopi bubuk biasa. Biaya bahan baku yang relative besar dipicu oleh tingginya harga beli kopi beras dari pedagang pengumpul dan petani kopi. Umumnya para pensuplai bahan baku berlokasi jauh pusat produksi kopi bubuk seperti di Kabupaten Kepahiang, Kabupaten Bengkulu Selatan, Kabupaten Kaur.

Aspek lain yang mendorong tingginya harga kopi karena harga kopi dunia juga mengalami peningkatan yang semula berkisar antara Rp 3.000 - Rp 4.000 saat penelitian berlangsung harga kopi mencapai kisaran Rp 6.000 - Rp 8.000 untuk per kilogram kopi beras (Wardhani dan Herman, 2000). Tingginya harga kopi beras ini juga di dorong oleh kelangkaan pasokan kopi beras karena sebagian besar pedagang pengumpul dan petani terutama di Kabupaten Bengkulu Selatan dan Kaur menjual kopi beras ke pedagang antara daerah yang berasal dari Propinsi Lampung.

Biaya penggunaan bahan bakar memberikan kontribusi relatif kecil terhadap biaya variabel. Namun persentase biaya bahan bakar kayu relatif lebih besar dibandingkan biaya bahan bakar solar. Penggunaan bahan bakar solar hanya diperuntukkan bagi mesin penggilingan kopi, sementara aktifitas produksi lainnya lebih banyak menggunakan bahan bakar kayu. Di satu sisi, kondisi ini memberikan keuntungan bagi pelaku industri kecil penggilingan kopi bubuk, karena kenaikan harga Bahan Bakar Minyak (BBM) belum memberikan dampak negatif siknifikan 
terhadap keberlanjutan usaha mereka di Kota Bengkulu. Di sisi lain, kelangkaan bahan bakar kayu dikhawatirkan akan terjadi mengingat munculnya hambatan suplai kayu karena gencarnya pelarangan eksploitasi kayu hutan yang sebagian besar merupakan bahan bakar utama industri kecil di Propinsi Bengkulu. Kondisi ini dialami sebagian besar usaha pengolahan berbahan baku pertanian di Bengkulu (Romdhon, 2004a).

Komposisi biaya tenaga kerja menunjukkan bahwa penggunaan tenaga kerja pria lebih besar dibandingkan tenaga kerja wanita. Umumnya tenaga kerja pria terserap pada aktifitas pengoperasian mesin penggilingan, perendangan kopi dan jagung, pembersihan biji kopi dan jagung, sedangkan tenaga kerja wanita hanya terserap pada aktifitas pembersihan biji kopi dan jagung, sebagian perendangan serta pengemasan termasuk aktifitas pemasaran. Disamping volume kerja yang relatif besar, perbedaan juga disebabkan oleh perbedaan upah, dimana upah tenaga kerja pria relatif lebih besar ketimbang upah tenaga kerja wanita.

\section{Persentase Biaya Tetap}

Biaya perawatan mesin dan biaya penyusutan mesin penggilingan merupakan biaya tetap dengan kontribusi terbesar. Artinya sebagian besar pemilik penggilingan kopu bubuk di Kota Bengkulu belum melakukan investasi baru terhadap peralatan produksi terutama mesin penggilingan. Rata-rata mesin penggilingan yang dimiliki telah berumur 11,4 tahun. Secara teoritis mesin penggilingan kopi tersebut telah mendekati bahkan melampaui umur ekonomisnya (rata-rata umur mesin penggilingan kopi berkisar 9 - 11 tahun). Pengoperasiannya membutuhkan biaya perawatan mesin yang relatif besar mencapai $26,64 \%$ sehingga efisiensi penggunaan bahan bakar dan optimalisasi produksi sulit dicapai.

Aspek-aspek lain yang berhubungan dengan kinerja industri kecil penggilingan kopi tetapi tidak berkaitan langsung dengan produksi antara lain aspek iklim usaha, aspek kelembagaan dan pemasaran. Biaya yang dikeluarkan oleh pemilik terutama biaya retribusi dan keamanan memberikan kontribusi yang sama yaitu 17,61\% per bulan, meksipun belum dapat dikatakan bahwa iklim industri kecil penggilingan kopi di Kota Bengkulu kurang kondusif. Angka ini relatif lebih besar dari biaya yang berkaitan langsung dengan produksi, seperti biaya penyusutan alat perendangan yang hanya berkisar $6-7 \%$.

42 | M. Mustopa Romdhon. Struktur Biaya dan Skala Usaha Ekonomis Penggilingan Kopi 
Hal lain yang harus dicermati berdasarkan hasil penelitian Romdhon (2004) pada industri kecil gula aren di Kabupaten Rejang Lebong menunjukkan bahwa persentase biaya tetap yang merupakan proksi investasi oleh pelaku usaha kecil relatif kecil. Kondisi yang sama ditunjukkan pada industri penggilingan kopi dimana persentase biaya tetap hanya berkisar $6-20$ persen saja, bandingkan dengan persentase biaya variabel untuk biaya bahan baku saja mencapai $73 \%$.

Realitas ini memberikan implikasi bahwa sebagian besar penggunaan modal usaha oleh industri kecil hanya untuk kegiatan operasional produksi. Sementara komposisi modal yang digunakan untuk aktifitas investasi seperti pembelian peralatan baru relatif tidak ada, yang ditunjukkan oleh belum adanya peremajaan peralatan (mesin penggilingan) meskipun telah melewati umur ekonomisnya. Pertanyaannya adalah kenapa hal ini dapat terjadi? berdasarkan temuan Romdhon (2004a, 2004b), Pearson, Bahri dan Gostch (2003) pada industri kecil olahan hasil pertanian dan usahatani padi fenomena ini timbul karena sebagian besar permodalan adalah modal sendiri. Kesulitan mengakses pinjaman modal dari lembaga keuangan terutama bank karena mereka tidak memenuhi kriteria layak pinjam 4C yang ditetapkan terutama agunan pinjaman. Kalaupun ada akses pinjaman dilakukan melalui lembaga keuangan non-formal seperti tengkulak/rentenir. Umumnya tingkat suku bunga yang dibebankan kepada pelaku usaha lebih tinggi dari lembaga bank, dan bersifat mengikat, meskipun aksesnya relatif mudah (birokrasi yang sederhana/tidak ada).

\section{Keuntungan Penggilingan Kopi Bubuk}

Rata-rata produksi yang dihasilkan per bulan oleh industri penggilingan kopi mencapai $80 \mathrm{~kg}$ per bulan untuk jenis kopi bubuk biasa dengan campuran jagung dan kopi bubuk spesial (bubuk kopi murni) masing-masing dalam kemasan berbeda. Harga rata-rata untuk kopi biasa berkisar Rp 6.000 - Rp 8.000 per kg dan kopi spesial berkisar Rp 14.000 - Rp 16.000 per kg. Meskipun persentase penggunaan biaya variabel untuk operasional lebih besar dibandingkan persentase biaya tetap untuk investasi, atau secara rata-rata total biaya mencapai kisaran 16 juta yang dikeluarkan namun secara umum pelaku industri kecil penggilingan kopi di Kota Bengkulu masih memperoleh profit (keuntungan) tiap bulannya. 
ISSN: $1412-8837$

\section{Skala Usaha Ekonomis Industri Kecil Penggilingan Kopi Bubuk}

Kondisi rasional bagi penggilingan kopi bubuk akan mampu memperoleh keuntungan bilamana usaha tersebut mencapai skala ekonomis, dimana biaya penggunaan faktor produksi mencapai minimum pada tingkat produksi maksimum. Dalam kondisi ini peningkatan produksi yang dilakukan pengusaha harus diikuti oleh peningkatan penggunaan faktor produski secara proporsional. Pengujian skala usaha dengan uji $\mathrm{t}$ memperlihatkan bahwa $\Sigma \beta=-0,32<1$, memperlihatkan bahwa industri kecil penggilingan kopi ububk di Kota Bengkulu berada pada skala Decreasing Return to Scale (DRS). Kondisi ini menurut Coelli (1998) memposisikan penggilingan kopi bubuk di Kota Bengkulu berproduksi dengan biaya rata-rata diatas biaya minimum dan peningkatan produksi selalu disertai dengan peningkatan biaya yang lebih besar sehingga usaha penggilingan kopi bubuk mengalami skala tidak ekonomis.

Penyebab dari skala tidak ekonomis secara teknis menurut Wardhani dan Herman (2000) bahwa alokasi dan ketersediaan input produksi seperti bahan baku kopi, bahan bakar, serta peralatan produksi secara belum sesuai dan tepat. Meskipun tenaga kerja produksi berpengalaman dan terampil. Secara finansial menurut Anwar (2002), dan berdasarkan temuan Romdhon (2004a, 2004b), Pearson, Bahri dan Gostch (2003) fenomena ini timbul karena sebagian besar permodalan berasal dari modal sendiri, sehingga peluang untuk pengembangan usaha menjadi terbatas.

Skala usaha yang ekonomis juga tidak terlepas dari kontribusi sejumlah faktor yang saling berinteraksi satu dengan lain terhadap keuntungan usaha. Hasil estimasi fungsi keuntungan cobb-douglass dengan menggunakan metode least square yang menunjukkan interaksi antar faktor tadi tersaji pada persamaan berikut.

$$
\begin{aligned}
& \Pi=649 . .356+0.54 X_{1}-0.03 X_{2}-0.12 X_{3}+0.21 X_{4}-0.32 X_{5}+0.24 X_{6}+0.06 X_{7}
\end{aligned}
$$

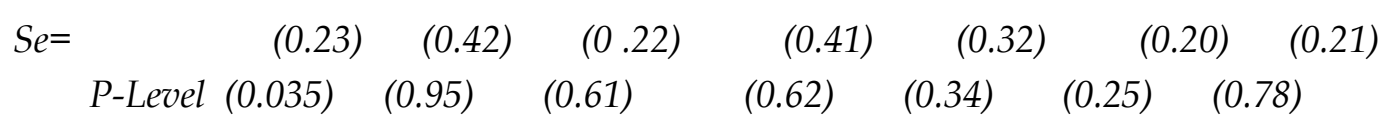

Hasil estimasi model pada 22 industri kecil penggilingan kopi bubuk di Kota Bengkulu menunjukkan nilai koefisien determinasi $\mathrm{R}^{2}=.49$. Artinya variasi keuntungan usaha yang diterima oleh usaha penggilingan kopi bubuk diterangkan oleh variabel bebas dalam model sebesar $49 \%$. Sementara 51\% dijelaskan variabel lain diluar model yang belum ikut dipertimbangkan.

44 | M. Mustopa Romdhon. Struktur Biaya dan Skala Usaha Ekonomis Penggilingan Kopi 
Variabel bebas yang berpengaruh nyata terhadap keuntungan hanya upah tenaga kerja yang bertanda positif. Artinya kenaikan upah tenaga kerja secara siknifikan akan meningkatkan keuntungan usaha kopi bubuk. Kondisi ini mengimplikasikan bahwa usaha ini masih bersifat padat karya yang memberikan kontribusi biaya sebesar $14 \%$ terhadap keseluruhan operasional usaha. Peningkatan permintaan kopi bubuk oleh konsumen yang terus meningkat mendorong pengusaha kopi bubuk meningkatkan suplai sehingga membutuhkan kuantitas tenaga kerja yang lebih besar dari semula.

Peningkatan jumlah tenaga kerja yang didorong oleh peningkatan suplai bahan baku terindikasi dari koefisien bahan baku yang bernilai positif. Artinya semakin besar peningkatan penggunaan bahan baku akan mendorong peningkatan keuntungan usaha, meskipun secara statistik tidak nyata. Hal ini timbul karena peningkatan permintaan kopi bubuk oleh konsumen, sehingga kebutuhan bahan baku juga meningkat. Peningkatan ini memperbesar penyerapan tenaga kerja oleh usaha ini seperti dikemukakan di atas. Ke depan peningkatan ini perlu diantisipasi secara cermat oleh usaha-industri kecil penggilingan kopi bubuk. Antisipasi dalam hal adanya kelangkaan pasokan beras kopi karena sebagian besar pedagang pengumpul dan petani terutama di Kabupaten Bengkulu Selatan dan Kaur menjual kopi beras ke pedagang antara daerah yang berasal dari Propinsi Lampung. Di sisi lain kelangkaan bahan baku disebabkan oleh penurunan produksi baik yang disebabkan oleh penurunan luas lahan tanam kopi maupun penurunan produktifitas hasil akibat pola budidaya yang masih tradisional.

Iklim usaha yang kodusif juga turut menentukan optimalitas perolehan pendpatan oleh para pelaku penggilingan kopi bubuk. Hasil analisis menunjukkan bahwa koefisien izin usaha dan lokasi usaha kopi bubuk bertanda positif meskipun tidak siknifikan. Hal ini berarti idealnya izin usaha yang dimiliki mendorong kenyamanan berusaha bagi pelaku usaha. Izin usaha dari departemen kesehatan yang dimiliki pelaku usaha juga merupakan jaminan bahwa produk kopi bubuk yang dihasilkan berkualitas dan aman untuk dikonsumsi sehingga diharapkan dapat mendorong peningkatan pembelian dan konsumsi kopi oleh konsumen yang sekaligus meningkatkan pendapatan mereka. Hal lain kopi sudah menjadi minuman keseharian masyarakat sehingga ada atau tidak jaminan dan legalitas tidak mengurangi keinginan konsumen untuk membeli dan mengkonsumsi kopi. 
ISSN: $1412-8837$

Lokasi usaha menurut Romdhon et al (2004a) yang strategis diyakini memberikan andil terhadap peningkatan perolehan pendapatan. Usaha-usaha kecil semacam ini umumnya berada di pusat-pusat perbelanjaan dan mudah dijangkau oleh konsumen terutama konsumen yang menggunakanjasa angkutan umum (angkot) maupun kendaraan pribadi. Namun variabel dummy yang digunakan bertujuan untuk menunjukkan bahwa lokasi penggilingan kopi bubuk menunjukkan bahwa lokasi usaha tidak berpengaruh nyata terhadap peningkatan pendapatan usaha.

Penurunan tingkat pendapatan usaha memang tidak terlalu besar yaitu hanya berkisar 0.03 persen jika terjadi kenaikan harga sebesar $1 \%$, hal ini terjadi karena sebagian besar pelaku usaha masih menggunakan bahan bakar non-minyak. Meskipun koefisien harga rata-rata bahan bakar bertandan negatif dan tidak nyata, namun kondisi ini perlu diantisipasi karena terjadinya kenaikan harga minyak mengingat keniakn ini akan mendorong penurunan tingkat pendapatan usaha.

\section{SIMPULAN DAN SARAN}

\section{Simpulan}

Berdasarkan hasil peneltian ini dapat disimpulkan bahwa umum pelaku industri kecil penggilingan kopi di Kota Bengkulu masih memperoleh profit (keuntungan) tiap bulannya. Namun sebagian besar industri kecil penggilingan kopi bubuk tersebut berdasarkan pengujian skala usaha dengan uji $t$ memperlihatkan bahwa $\Sigma \beta=-0,32<1$, artinya industri kecil penggilingan kopi bubk di Kota Bengkulu berada pada skala Decreasing Return to Scale (DRS). Hal ini dipengaruhi secara siknifkan oleh khususnya oleh upaha tenaga kerja.

\section{Saran}

Dengan kondisi usaha yng sebagian besar berada pada skala usaha yang belum ekonomis maka diperlukan asisten baik oleh pemerintah maupun swasta besar serta perguruan tinggi dalam rangka peningkatan daya saing kompetitif idnsurti tersebut. Asisten teknis dapat diberikan dalam bentuk pelatihan teknis penggilingan kopi bubuk secara higienis dan aman berdasarkan kebutuhan pasar lokal maupun pasar regional dan ekspor. Sedangkan asisten manajerial dapat diberikan dalama bentuk pelatihan pengelolaan usaha berdasarkan manajemen modern seperti pelatihan penyusunan pembukuan usaha.

46 | M. Mustopa Romdhon. Struktur Biaya dan Skala Usaha Ekonomis Penggilingan Kopi 


\section{DAFTAR PUSTAKA}

Anwar, A. 2002. Suatu Arah Tentang Analisis Institusi Sistem Kontrak Pertanian di Wilayah Perdesaan. Program Studi PWD, IPB. Bogor.

Coelli, T, D.S. Prasada Rao, and George E.Battese. 1998. An Introduction to Efficinecy and Productivity Analysis. Kluwer Academic Publisher Group. USA.

Hafsari, S.E. 2004. Kontribusi dan Prospek Kopi Rakyat terhadap PDRB Subsektor Perkebunan di Propinsi Bengkulu. Seminar Akademik. FAPERTA UNIB.

Hayami, Y dan V.W. Ruttan. 1984. Agricultural Development, An International Perspective. The John Hopkin University Press, Baltimore and London.

Hendayana, R. 1998. Faktor-faktor yang Mempengaruhi Peluang Petani Menerapkan Teknologi Baru Dalam Usahatani Padi (kasus SUTPA di Propinsi Lampung). Pusat Kajian Sosial Ekonomi Pertanian. Badan Litbang Deptan. Bogor.

Hobbs, J.E. 1997. Measuring The Importance of Transaction Cost in Cattle Marketing. Amer, J. Agr. Econ 79(4) :1083-1095.

Juita, E. 2004. Peranan Agroindustri dalam Perekonomian Kota Bengkulu. Seminar Akademik. Pertanian UNIB.

Nawireja, IK. 2002. Adopsi Kapas Bt : Aplikasi Model Multinomial Logit. Ilmu Komunikasi Program Pasca Sarjana. Fisip UI

Nugroho, H. 2000. Uang, Rentenir, dan Hutang Piutang di Jawa. Pustaka Pelajar Center for Critical Social Studies (CCSS). Yogyakarta.

Romdhon, M.M et al. 2004a. Skala Usaha dan Pemasaran Industri Kecil Gula Aren dalam Sistem Ekonomi Kelembaaan Principle Agents di Kabupaten Rejang Lebong. Laporan Penelitian Hibah SP-4. Jurusan SOSEK Pertanian. UNIB

Romdhon, M.M and Indra, C. 2004b. The Competitiveness And Efficiency Of RiceFarming Systems In North Bengkulu District, Bengkulu Province. Final reports to DAI Inc through FPSA Programs

Rubienfeld and Pindyck, R.S. 1997. Econometric Models and Econometric Forecasts. Irwin McGraw-Hill Companies

Singarimbun, M dan Sofian Effendi. 1989. Metode Penelitian Survai. LP3ES.Jakarta

Suryo Wardhani dan Herman. 2000. Perkembangan dan Prospek Komoditas Kopi. Tinjauan Komoditas Perkebunan (kelapa sawit, karet, gula, kopi, kakao dan teh) Vol.1 No.1 September 2000. Asosiasi Penelitian Perkebunan Indonesia dan Direktorat Jenderal Perkebunan.Bogor

Yuanda, Y. 2004. Studi Tentang Faktor-Faktor yang Mempengaruhi Perubahan Lahan Kopi di Propinsi Bengkulu. Skripsi.Jurusan SOSEK Pertanian UNIB.

Yusdja, Y dan Rosmiyati Sajuti. 2002. Skala Usaha Koperasi Susu dan Implikasinya bagi Pengembangan Usaha Sapi Rakyat. JAE. hal 48n 63 Vol. 20 No.1 Mei. 